Tourism 2009, 19/1-2

\author{
Jerzy Wyrzykowski \\ Wrocław University \\ Institut of Geography \\ jwyrzykowski@poczta.onet.pl
}

\title{
THE SIGHTSEEING ATTRACTIONS OF WROCŁAW AND THEIR POTENTIAL EXPLOITATION
}

\begin{abstract}
The article presents the more important results of research concerning the sightseeing attractions of Wrocław which can then be used to inform the organisation of the tourism offer of the city.
\end{abstract}

Key terms: sightseeing attractions, tourism offer, tourist routes.

In the Strategic Plan for Tourism Development in Poland (1971) Wrocław was designated as one of eight large national sightseeing centres. A detailed analysis of the city's tourist potential was carried out by MIKUŁOWSKI \& WYRZYKOWSKI (1996a \& 1996b) in A Study of the Conditions and Directions for the Spatial Development of the Municipality of Wroctaw (1997) and the results were used in a project supervised by Wyrzykowski entitled Tourism in Lower Silesia: its present state and directions for development (2004). It is worth briefly quoting some most important results from that research.

Generally speaking, tourism attractiveness is composed of a variety of factors: artistic, historic, cultural, landscape and aesthetic. They are all referred to as 'tourism values' demonstrated through their adaptation into tourist functions and their accessibility, for example the chance to enter a building of interest and see its interior.

It is natural that in a city it is the anthropological and cultural elements that make up its tourism value. Therefore buildings (or whole complexes) with their special historic, artistic or technological features are the first sites to be mentioned and mostly they are legally protected as structures of historic or landscape value.

In the accepted classification of urban tourism resources, the common division into architectural and buildings included because of their specific functions, has been adopted. The starting point for this division is the initial function of a building but in many cases this will have changed over time.

The basic condition for a site to become an attraction is its actual existence and presence, and information alone is not an attraction without a visible point of reference. On the other hand, however, information is crucial to its value and what is included in professional tourism literature or delivered orally by a licensed guide, is taken into account when assessing its value.

The evaluation applied in this analysis, with reference to the tourism attractiveness of individual sites and complexes, concerns each category separately and sites are only comparable within a category. The scores are relative and without mathematical value. The evaluation has been worked out comparatively through the application of a three-point scale: 'highest', 'high', 'average'. Only sites of at least average tourism importance for Wrocław are evaluated. Others are supplementary only, constituteing background for those evaluated, and are introduced later. The authors tried to take guidance from the interests and opinions of everyday 'mass' tourists, and take advantage of their experience as well as from guides showing tourist groups around the city.

Religious monuments are Wrocław's main tourism attraction because of their large number, their high artistic and historic value, and as representatives of architectural styles. The greatest concentration of churches is found in the area of the Old Town and Ostrów Tumski. Gothic churches, some with baroque interiors, are dominant while there are also examples of high-quality baroque. Some contemporary churches built in the second half of the $20^{\text {th }} \mathrm{c}$. receive a lot of interest, too.

Fifty three religious sites were analysed and graded: highest -7 , high - 28, average - 18. The 'highest' group included the churches of St. Mary Magdalene, St. Adalbert, the Holy Name of Jesus, St. Clara, 
Cathedral of St. John the Baptist, Holy Cross and St. Bartholomew, and the Holy Virgin Mary.

In Wrocław there are a comparatively large number of public buildings, mostly concentrated in the area of the Old Town and its surroundings due to their service function and that they must be easily accessible. They are usually the local government offices, specific departments and other institutions, or have social, cultural, business or shopping functions. Mostly they are magnificent edifices of interesting exterior architecture and unusual interior design.

Forty six public buildings were analysed and graded: highest - 6, high - 19, average - 21. The 'highest' group included the Old Town Hall, the Opera, the University of Wrocław complex, the Hala Ludowa, the Central Railway Station and the Olympic Stadium.

Palaces, castles and manor-houses are always interesting to tourists, especially when they serve as museums and are furnished according to their original purpose. In Wrocław such buildings were of German provenance and as such were not properly restored after the war. Their original purpose was often altered.

Fifteen residential buildings were analysed and graded: highest -0 , high -8 , average -7 . The city has no preserved residential monuments in the 'highest' category. However in the future the situation may change due to renovations, for example the Spatgen Palace in the former royal castle.

In Wrocław there are the preserved remains of old fortifications - historic mediaeval as well as new dating from WW II. Mediaeval fortifications are present exclusively in the area of the Old Town. 18 th c. structures were pulled down at the beginning of the $19^{\text {th }}$ c., and among $20^{\text {th }}$ c. fortifications, mainly from WW II, only those easily accessible located in the centre have been chosen. Those far away from the centre and difficult to reach have been omitted.

Seventeen fortifications were analysed and graded: highest - 1, high - 8, average - 8, with the Arsenal complex as the largest and most interesting of Wrocław's military structures. Today, with reference to its original function, it houses the Military Museum (a department of Wrocław City Museum) with a collection of historical and military exhibits.

Technological structures and installations in Wrocław are mostly connected to the Odra and taken care of by the Museum of the River Odra (in preparation). The city is renowned for its large number of bridges, some of which are interesting from an architectural or technological viewpoint. However, in a tourism assessment few of them receive high scores. It is expected that in the future the water tower on $\mathrm{Na}$ grobli Street will become one of the most attractive technological structures in Wrocław, but only after its opening to tourists as a museum.

Forty buildings, structures and technological installations were analysed and graded: highest - 2, high - 19, average - 19. Two structures: the Grunwaldzki suspension bridge of an unusual construction and the steel 'needle' (Iglica) almost 100 metres high were in the 'highest' category.

Wartime damage to the urban fabric was common and only a part of the Old Town has been rebuilt while some quarters and built-up areas were totally destroyed. Therefore even those streets, squares or neighbourhoods indicated as tourism attractions, are not homogenous or complete. The most interesting residential areas are located within the Old Town area and their condition is quite good at present. On the other hand, many valuable frontages of town houses built at the turn of the $20^{\text {th }}$ c. do not qualify because of their poor condition as well as their damaged and neglected façades, once both valuable and beautiful.

Twenty seven complexes of town houses and residential buildings were analysed and graded: highest - 1, high - 20, average - 5. The western frontage of the Town Square received a 'highest' score as it includes the wealthiest burgher houses with their interesting history, form and function.

Monuments usually constitute a supplementary, decorative element of a town and as such are mostly visited in passing. Sometimes, however, they can become a target for a tourist. Quite often their size, scale or location impairs their visibility and presentation as they get overgrown by plants in parks or concealed by urban structures. Their artistic, historical, aesthetic or ideological value sometimes however predestines them to become prominent sightseeing attractions. In many cases monuments commemorate people or historic events connected with the places in which they are located.

Thirty eight statues and monuments were analysed and graded: highest - 4, high - 20, average - 14 . Those on the Town Square are of primary importance - Aleksander Fredro and a pillory - but St. John Nepomuk on Ostrów Tumski and the monument to the Victims of Katyń next to Racławice Panorama are equally interesting.

Most museums are located in the area of the Old Town, others nearby. Art galleries are traditionally the most popular among tourists, shown by the fact that they sell most tickets. Some specialised and unique museums are also of primary importance, for example the Museum of Post and Telecommunication. The rotunda of the Racławice Panorama, housing a large, $19^{\text {th }} \mathrm{c}$. painting, moved to Wrocław from Lvov, is a new, post-war addition to the city's 
collection of museums and has been very successful in attracting large numbers of tourists.

Sixteen museums were analysed and graded: highest -3 , high -8 , average -3 . Among them the most interesting are the National Museum, the Racławice Panorama, the Historical Museum in the Old Town-Hall, the Museum of Cemetery Art and the Museum of Wrocław University. Some are located in interesting buildings which by themselves are attractive to the tourist from an architectural point of view.

Wrocław cemeteries in use today do not usually have any extraordinary historical or monumental value as the political continuity of the region of Lower Silesia was broken after WWII. Former German tombstone monuments were destroyed and so do not attract the sentimental and cultural interest of German tourists. Nevertheless two Jewish cemeteries survived - one still in use, the other turned into a museum due to its exceptional historical value. Even though cemeteries are not typical attractions they may become a point of interest to visitors and this concerns some civilian and military cemeteries.

Nine cemeteries were analysed and graded: highest -0 , high -6 , average -3 . The Old Jewish Cemetery, which is in the 'highest' category thanks to its original and magnificent tombstones, was already taken into account in the museum section of this article.

Among natural sightseeing attractions only those on a large scale, such as city parks and landscaped areas with small-scale architectural elements, and natural river channels or man-made canals or lakes, have tourist interest. Among Wrocław's dozens of parks and wooded areas, 25 complexes were chosen and classified. Featuring interesting plant compositions, they fall under the conservationists' care as monuments of culture, contain 'monuments of nature' or constitute extraordinary compositions of greenery and water or landscaping.

The attractiveness of parks is measured by the abundance of plant species (including those acclimatised from distant regions), the age of specimens and the artistic value of the gardens. It is worth mentioning that most parks and gardens in Wrocław are professionally cared for and those of the 'highest' interest to the tourist are:

- Szczytnicki Park with its Japanese Garden and four more historical sections,

- Południowy Park with its viewing pavilion, concert 'shell', pond and garden of perennials,

- Old Town Promenade Park laid out along the mediaeval moat,

- the University of Wrocław Botanical Gardens featuring exotic trees and shrubs, interesting geological sections, and palm and cactus houses.
Independent of these, some 'monuments of nature' have been singled out. They are usually individual trees, groups of trees or avenues. Most often they are ancient oaks distinguished by their extraordinary size (measured by their trunk circumference) or large plane trees, which have become acclimatised in Poland. All of them, though not numerous, are classified as highly attractive since they surely deserve such a score regardless of their different natural features.

Elevated viewpoints that make the observation of the city's panorama possible usually attract large numbers of tourists. In Wrocław the most popular are the tower of St. John the Baptist's Cathedral in Ostrów Tumski (Cathedral Island) and the tower of St. Elizabeth's Church close to the Rynek (Old Town Square). Apart from existing viewpoints, potential ones in preparation for opening (or expected in the future) are also presented.

Eight towers and observation platforms were analysed and graded: highest -3 , high -5 , average 0 . Among the few existing open to the public the two offer the most interesting panorama of Wrocław while in the future they may be joined by the tower of St. Mary Magdalene Church.

The landscape value of Wrockaw may best be appreciated from the viewpoints mentioned above in connection to the Odra. The specific nature of Wrocław's topographical location is such that it was built historically on the natural spot most suitable for crossing the river and the city's urban development over the centuries consequently took the local hydrographical system into account and re-shaped it. In consequence the river channel was split into many branches, numerous islands and high embankments appeared, hydro-technological buildings and installations came into being. Many riverside boulevards and bridges offer an interesting landscape best appreciated on foot or by bicycle. Thirty six sites and panoramic views were analysed and graded: highest -4 , high -15 , average -17 .

Finally it should be mentioned that tourists arriveing In Wrocław, especially for longer than one day and staying overnight, are often interested in the cultural events which may be considered attractions as well. Wrocław, one of the largest cities of Poland and the capital of Lower Silesia, boasts a welldeveloped network of theatres and musical institutions (over a dozen establishments). It is noteworthy that tourists not only visit these as a part of their sightseeing itinerary, but also to attend such events, which in fact, is the reason why they come to the city. This happens for people from Lower Silesia as well as those from all round the country, for example when the opera stages one of its magnificent shows, either in the open-air or in the Hala Ludowa. 
The range of venues for theatre events in Wrocław is quite large however an attempt to evaluate them has been undertaken. Generally speaking most tourists come to attend opera or theatre shows and music concerts, depending on the repertoire.

The total number of sites attractive to tourists in all categories comes to 337, and on the three-point scale were graded: 38 - highest; 174 - high; 125 average (Table 1). It is to be noted that level of attractiveness can be determined only within each type.

T a b l e 1. Wrocław tourism attraction resources

\begin{tabular}{|l|c|r|r|r|}
\hline \multirow{2}{*}{ Type of attraction } & \multirow{2}{*}{$\begin{array}{c}\text { Number } \\
\text { of sites and } \\
\text { complexes }\end{array}$} & \multicolumn{3}{|c|}{ Tourism attractiveness } \\
\cline { 3 - 5 } & & highest & high & average \\
\hline $\begin{array}{l}\text { Churches, } \\
\text { monasteries and } \\
\text { sacred buildings }\end{array}$ & 53 & 7 & 28 & 18 \\
\hline Public buildings & 46 & 6 & 19 & 21 \\
\hline Residential buildings & 15 & 0 & 8 & 7 \\
\hline Fortifications and & 17 & 1 & 8 & 8 \\
\hline Technological & 40 & 2 & 19 & 19 \\
\hline Town houses and \\
residential buildings
\end{tabular}

S o u r c e: MIKUŁOWSKI \& WYRZYKOWSKI 1996a, and WYRZYKOWSKI (ed.), 2004.

The division according to type of site, shows that in terms of numbers, churches, monasteries and other sacred structures are dominant - 53 buildings or complexes; followed by public buildings -46 , technological structures and installations - 40; monuments 38; sites and panoramic views of the Odra - 36; town houses and residential buildings - 26; parks 25; fortifications and bunkers - 17; museums - 16; residences - 15; cemeteries - 9; observation points and 'monuments of nature' - 8 each.

As mentioned at the beginning of this paper the elements described here do not exhaust the entire stock of sightseeing attractions of Wrocław. Another category would be included if the city fabric is treated as an attraction which might be considered supplementary, deepening cognitive interests of both tourists and inhabitants of Wrocław.

The distribution of tourism attractions is concentrated in the complex of the Old Town (50\%) and its surroundings (25\%) with the other $25 \%$ spread over other districts of the city.

The results of this evaluation confirm that Wrocław is one of Poland's most attractive urban centres for tourists and its cultural value compared to Warsaw, Kraków, Poznań or Gdańsk. Its attractiveness is connected to interesting sites and buildings accessible to tourists, places which are traces of the thousand-year-old history of the city from the early Middle Ages to the beginning of the $21^{\text {st }} \mathrm{c}$.

An additional embellishment, and a characteristic feature of Wrocław's sightseeing value, is its multicultural atmosphere stemming from the historical variation in the city's nationality. It is especially attractive for tourists from neighbouring countries: Germans, Czechs, Austrians and for Jewish visitors.

Poles have considerably contributed to the urban form of Wrocław especially in the Mediaeval and post-WWII periods. The last decade of the $20^{\text {th }}$ c., with the first years of the $21^{\text {st }}$, have brought new and architecturally interesting examples of buildings as well as the further renovation of historical monuments, especially within the Old Town and the central districts of Wrocław.

Large-scale polling among visitors carried out at the end of 1990s (WYRZYKOWSKI et al., 1999), giving the opinions of both foreign and domestic tourists, allows a contrast with the present evaluation. Tables 2 and 3 present the places most often visited by them.

T a b l e 2. Sites visited by domestic respondents

\begin{tabular}{|l|r|}
\hline \multicolumn{1}{|c|}{ Sites } & $\begin{array}{c}\text { Number } \\
\text { of visitors } \\
\text { (\% of total) }\end{array}$ \\
\hline Racławice Panorama & $1472(84.4)$ \\
\hline St. John the Baptist's Cathedral & $1222(70.0)$ \\
\hline Zoological Garden & $1186(68.0)$ \\
\hline Town Hall & $1173(67.2)$ \\
\hline Hala Ludowa & $858(49.1)$ \\
\hline Botanical Garden & $733(42.0)$ \\
\hline National Museum & $716(41.0)$ \\
\hline St Mary of the Sands & $702(40.2)$ \\
\hline $\begin{array}{l}\text { Main Building of the University of Wrocław } \\
\text { with the Leopoldinum Hall }\end{array}$ & $625(35.8)$ \\
\hline Olympic Stadium & $517(29.6)$ \\
\hline Others & $94(5.3)$ \\
\hline
\end{tabular}

So u r c e: Wyrzykowski et al., 1999.

According to the Polish tourists questioned, the ten most interesting sites in Wrocław are (ranked from the highest down): Racławice Panorama, St. John the Baptist's Cathedral, Zoological Garden, Town Hall, Hala Ludowa, Botanical Garden, National Museum, Mary of the Sands, the Main Building of the University of Wrocław with the Leopoldinum Hall, the Olympic Stadium. According to foreign 
visitors: the Town Hall, St. John the Baptist's Cathedral, Racławice Panorama, the University with the Leopoldinum Hall, St Mary of the Sands, National Museum, Botanical Garden, Hala Ludowa, Zoological Garden and the Olympic Stadium.

$\mathrm{T}$ a b l e 3 . Sites visited by foreign respondents

\begin{tabular}{|l|c|}
\hline \multicolumn{1}{|c|}{ Sites } & $\begin{array}{c}\text { Number } \\
\text { of visitors } \\
\text { (\% of total) }\end{array}$ \\
\hline Town Hall & $650(85.9)$ \\
\hline St. John the Baptist's Cathedral & $495(65.4)$ \\
\hline Racławice Panorama & $486(64.2)$ \\
\hline $\begin{array}{l}\text { Main Building of the University with } \\
\text { the Leopoldinum Hall }\end{array}$ & $409(54.0)$ \\
\hline St Mary of the Sands & $311(41.4)$ \\
\hline National Museum & $219(28.9)$ \\
\hline Hala Ludowa & $218(28.8)$ \\
\hline Botanical Garden & $159(21.0)$ \\
\hline Zoological Garden & $131(17.3)$ \\
\hline Olympic Stadium & $97(12.8)$ \\
\hline Others & $49(6.5)$ \\
\hline
\end{tabular}

So u r c e: Wyrzykowski et al., 1999.

In order to provide a maintenance and servicing programme it is crucial to consider two factors: length of visit and tourism capacity (site throughput).

Length of visit is the amount of time that an average tour participant needs to visit one site or area. When determining this time the interests of an averagely-educated visitor are taken into account.

$\mathrm{T} \mathrm{a} \mathrm{b} \mathrm{l} \mathrm{e} 4$. Tourism capacity and the necessary length of visit for the more significant attractions in Wrocław

\begin{tabular}{|l|c|c|}
\hline \multicolumn{1}{|c|}{ Name of site } & $\begin{array}{c}\text { Tourism capacity } \\
\text { by number } \\
\text { of tourism } \\
\text { groups }\end{array}$ & $\begin{array}{c}\text { Necessary } \\
\text { length of visit } \\
\text { (in hours) }\end{array}$ \\
\hline Jewish Cemetery & 5 & 2 \\
\hline Hala Ludowa & $4-5$ & 1 \\
\hline $\begin{array}{c}\text { St. John the Baptist's } \\
\text { Cathedral (including } \\
\text { the viewing platform } \\
\text { on the tower) }\end{array}$ & 5 & 2 \\
\hline $\begin{array}{c}\text { St. Elizabeth's Basilica } \\
\text { (including the viewing } \\
\text { platform on the tower) }\end{array}$ & 30 & 1.5 \\
\hline National Museum & 36 & 1,5 \\
\hline Botanical Garden & 100 & 1,5 \\
\hline Zoological Garden & 4 & $2-3$ \\
\hline Racławice Panorama & 6 & 1.5 \\
\hline Town Hall & 10 & 1.5 \\
\hline Olympic Stadium & $6-7$ & $1.5-2$ \\
\hline $\begin{array}{c}\text { Main Building of the } \\
\text { University with the } \\
\text { Leopoldinum Hall }\end{array}$ & 5 & 2 \\
\hline
\end{tabular}

S o u r c e: STĘŻOWSKA 2006.
The maximum capacity of a tourism attraction (ROGALEWSKI 1972, uses the term 'site capacity') means the number of people which, under optimum conditions, may simultaneously visit, watch or in any other way take advantage of a given site and not cause damage.

Approximations of capacity and the necessary length of a visit for selected sightseeing attractions in Wrocław were prepared by STĘŻOWSKA (2006) for her master's thesis (Table 4). They were based on an optimal organization of sightseeing at every site and the length of time needed to deliver information about it through consulting tourist guides and the administrators.

As a result of assessing 'tourism value' and development, its exploitation, and surveys of tourist opinions, six tourism products have been designed and should be included in the tourism development strategy in Wrocław (MIKUŁOWSKI \& WYRZYKOWSKI 1996b).

- general sightseeing: half-day; one-day; two-day; three-day and longer;

- sentimental sightseeing: German, Israeli, Polish Diaspora;

- business sightseeing;

- participation in conferences and congresses;

-participation in events: trade fairs, culture, sports;

- serving transit tourists: travellers by plane or train, drivers and passengers of private cars, lorry drivers.

Each product has been assigned the basic elements of an offer, the demand for services and what is to be used by tourists.

The organisation is based on a system of routes for tourists who visit the city and use its services, considering transport, accommodation, gastronomy, shopping, culture, recreation and so on.

The routes which are suggested here result mainly from the experience of existing guides and take mostly into account tourists who are visiting the city for the first time, thus offering the main and most interesting attractions. At the same time they allow a certain broadening of programme and interests into other fields. It must be mentioned that tourism routes are not, as for now, marked. Guidebooks describe individual places to be seen in an arrangement proposed by their authors and, mostly, from the point of view of a tourist on foot.

The production of a sightseeing programme always depends on the conditions concerning a group or individual tourists: the time to be devoted to sightseeing, tourism services booked in advance, weather conditions, their affluence, preferences stemming from individual interests of participants, their physical and mental capability. As a result an arrangement of activities, modified in time and space, to be agreed 
every time between the group and the guide, or adopted independently by individual tourists.

The suggestions encompass routes on foot, routes by coach and on foot, coach tours of the centre and coach tours outside the centre. Two routes on foot (Old Town Route and Szczytnicka Route), one route by coach and on foot, two coach tours of the centre (the Old Town and Szczytnicki Park with the Olympic Stadium) and six coach tours leading outside the centre to Leśnica, the Bielanski motorway junction, Gaj, Sepolno, Psie Pole and Karłowice were proposed.

The starting and final points of a sightseeing programme are some of its most important elements. The Central Railway Station was accepted as such a spot for groups travelling by rail while for coach groups it is the large car park behind the Main Post Office building in Podwale Street (considered optimally located and the largest possible). The coach park next to the Racławice Panorama may also be used for the same purpose.

An evaluation of the tourism resources of Wrocław, attempts to establish maximum capacity and necessary length of visit for the more important attractions, suggestions for products and routes, and should constitute the basis for tourism spatial policy in Wrocław.

\section{BIBLIOGRAPHY}

MIKUŁOWSKI, B., WYRZYKOWSKI, J., 1996a, Ocena walorów turystycznych Wrocławia. Część I materiałów do Studium uwarunkowań..., 1997, Wrocław (typewriting).

MIKUŁOWSKI, B., WYRZYKOWSKI, J., 1996b, Zagospodarowanie turystyczne, organizacja ruchu turystycznego, produkty turystyczne i segmentacja rynku turystycznego. Część II do Studium uwarunkowań..., 1997, Wrocław (typewroting).

„Plan kierunkowy zagospodarowania turystycznego Polski”, 1971, Zakład Zagospodarowania Turystycznego GKKFiT, Wrocław.

ROGALEWSKI, O., 1972, Podstawy gospodarki przestrzennej w turystyce, Ruch Turystyczny, nr 1/2.

STĘŻOWSKA, M., 2006, Próba oceny pojemności turystycznej ważniejszych obiektów krajoznawczych Wrocławia, Master's thesis at the Wrocław University Wrocław.

Studium uwarunkowań $i$ kierunków zagospodarowania przestrzennego gminy Wrocław, 1997, Biuro Rozwoju Wrocławia i Wydział Architektury Politechniki Wrocławskiej, Wrocław (typewriting).

WYRZYKOWSKI, J. at all, 1999, Walory i oferta turystyczna miasta w opinii turystów, Wrocław 2000 Plus, z. 1(28), Urząd Miejski Wrocławia Biuro Rozwoju Wrocławia, Wrocław.

WYRZYKOWSKI, J. (ed.), 2004, Turystyka na Dolnym Ślasku. Stan i kierunki rozwoju, Wydawnictwo AWF we Wrocławiu, Wrocław. 